\title{
The use of hydrothermal methods in the synthesis of novel open-framework materials
}

\author{
SRINIVASAN NATARAJAN*, SUKHENDU MANDAL, PARTHA MAHATA, \\ VANDAVASI KOTESWARA RAO, PADMINI RAMASWAMY, \\ ABHISHEK BANERJEE, AVIJIT KUMAR PAUL and K V RAMYA \\ Framework Solids Laboratory, Solid State and Structural Chemistry Unit, Indian Institute of Science, \\ Bangalore 560012 \\ e-mail: snatarajan@sscu.iisc.ernet.in
}

\begin{abstract}
The preparation of inorganic compounds, exhibiting open-framework structures, by hydrothermal methods has been presented. To illustrate the efficacy of this approach, few select examples encompassing a wide variety and diversity in the structures have been provided. In all the cases, good quality single crystals were obtained, which were used for the elucidation of the structure. In the first example, simple inorganic network compounds based on phosphite and arsenate are described. In the second example, inorganic-organic hybrid compounds involving phosphite/arsenate along with oxalate units are presented. In the third example, new coordination polymers with interesting structures are given. The examples presented are representative of the type and variety of compounds one can prepare by careful choice of the reaction conditions.
\end{abstract}

Keywords. Hydrothermal methods; open-framework; single crystal XRD.

\section{Introduction}

The synthesis and study of novel inorganic compounds, especially those with specific functional groups, constitute an important area of research. A large number of synthetic approaches involving both mild as well as extreme conditions have been employed for the preparation of such compounds. Of these, compounds possessing extended network structures are an important class. In recent years, solids possessing extended structures have been attracting attention for their many applications in the area of catalysis, sorption and separation processes, both actual as well as potential. Many of these compounds have been prepared employing hydrothermal methods.

The term hydrothermal is purely of geological origin, which generally refers to any heterogeneous reaction in the presence of aqueous solvents or mineralisers under high pressure and temperature conditions to dissolve and recrystallise materials that are relatively insoluble under ordinary conditions. Sir Roderick Murchison (1792-1871), the British Geologist, used this term to describe the action of water at elevated temperature and pressure in bringing about the changes in the earth's crust leading to the formation of various

\footnotetext{
*For correspondence
}

minerals. The first successful commercial application of the hydrothermal method began with the mineral extraction or ore beneficiation during the 19th Century. Karl Josef Bayer (1871-1908) used sodium hydroxide to leach bauxite in 1892 as a process for obtaining pure aluminum hydroxide, under hydrothermal conditions. Further importance of the hydrothermal technique for the synthesis of inorganic compounds in a commercial way was realized soon after the synthesis of large single crystals of quartz and later aluminosilicate zeolites by Barrer. ${ }^{1,2}$ The versatility of the hydrothermal procedure, mainly due to the mineralizing role of water, is quite apparent as it forms many minerals with considerable structural variety. Open aluminosilicate zeolite frameworks are stabilized during growth by being filled with guest molecules and hydrothermal method provides a facile route.

One of the important aspects of the hydrothermal method is to get the reactants, which are otherwise difficult to dissolve, into solution under the action of mineralisers or solvents. This is similar to the chemical transport reactions, which prompted definition of hydrothermal reactions as a special case of chemical transport reactions. Many of the fundamental physical properties of water like fugacity, dielectric constant, density etc. undergo considerable changes during the 
hydrothermal reaction at elevated temperatures. This has resulted in using this method for many types of reactions. Though traditionally hydrothermal method has been employed for the growth of large single crystals (quartz) and also for the leaching of ores during metal extraction, recent research has clearly shown that it is also highly beneficial for the preparation of new types of solids, especially complexes, coordination polymers ${ }^{3}$ and microporous materials. ${ }^{4}$

Hydrothermal crystallizations are multi-component heterogeneous reactions involving several processes including equilibrium reactions, nucleation and growth. In many of the preparations of microporous solids under hydrothermal conditions, an organic amine molecule is used. The role of the organic amine molecule in the synthesis of such solids can be classified into three types: templating, structure-directing and space-filling. Here 'templating' refers to the formation of a unique structure, which reflects the geometrical and electronic structure of the template. Structure-direction describes the process where a specific organic amine preferentially leads to the synthesis of a structure by suitably influencing factors such as $\mathrm{pH}$, solubility and electrostatic interactions. Space-filling is a process in which the organic amine excludes water and enhances the interactions in the organic-framework composite and thereby increases the thermodynamic stability.

During the synthesis of porous solids, irrespective of the role of the amine molecules, the amine molecules are, in general, located in cavities or channels and appears to direct the formation of a particular structure. The amine molecules can be removed by calcination, acid-leaching etc. to give a solid with large porous structure. Such solids are useful in the areas of catalysis, sorption and separation processes.

We have been employing the hydrothermal methods extensively for the past few years. The intense research activity resulted in many new compounds possessing a variety of structures. The compounds have zero-, one-, two- and three-dimensionally extended structures. The lower dimensional structures appear to be precursors for the formation of the structures of higher dimensionality. In what follows, we present a few select examples of open-framework compounds prepared in our laboratory using the hydrothermal method. The compounds, $\left[\mathrm{Co}^{\mathrm{II}}\left(\mathrm{C}_{10} \mathrm{H}_{8} \mathrm{~N}_{2}\right)\right.$ $\left.\left(\mathrm{H}_{2} \mathrm{PO}_{3}\right)_{2}\right], \mathbf{I},\left[\mathrm{C}_{6} \mathrm{~N}_{3} \mathrm{H}_{20}\right]\left[\mathrm{Zn}_{2}\left(\mathrm{AsO}_{4}\right)\left(\mathrm{HAsO}_{4}\right)_{2}\right] \cdot 2 \mathrm{H}_{2} \mathrm{O}$, II, $\left[\mathrm{NH}_{3}\left(\mathrm{CH}_{2}\right) \mathrm{CH}\left(\mathrm{NH}_{3}\right) \mathrm{CH}_{3}\right]_{3}\left[\mathrm{Fe}_{6}\left(\mathrm{AsO}_{4}\right)_{2}\left(\mathrm{HAsO}_{4}\right)_{6}\right.$ $\left.\left(\mathrm{C}_{2} \mathrm{O}_{4}\right)_{3}\right]$, III, [C $\left.\mathrm{C}_{5} \mathrm{~N}_{2} \mathrm{H}_{14}\right]\left[\mathrm{Fe}_{4}\left(\mathrm{HPO}_{3}\right)_{2}\left(\mathrm{C}_{2} \mathrm{O}_{4}\right)_{3}\right], \mathbf{I V}$, $\left\{\mathrm{Gd}\left(\mathrm{H}_{2} \mathrm{O}\right)_{3} \mathrm{Co}\left[\mathrm{C}_{5} \mathrm{~N}_{1} \mathrm{H}_{3}(\mathrm{COO})_{2}\right]_{3}\right\}, \mathbf{V}$ and $\left\{\mathrm{Zn}\left(\mathrm{H}_{2} \mathrm{O}\right)_{2}\right.$
$\left.\left[\mathrm{C}_{5} \mathrm{~N}_{1} \mathrm{H}_{3}(\mathrm{COO})_{2}\right]\right\} . \mathrm{H}_{2} \mathrm{O}, \mathbf{V I}$, illustrate the efficacy of this method.

\section{Experimental}

\subsection{Synthesis}

2.1 a $\left[\mathrm{Co}^{I I}\left(\mathrm{C}_{10} \mathrm{H}_{8} \mathrm{~N}_{2}\right)\left(\mathrm{H}_{2} \mathrm{PO}_{3}\right)_{2}\right]$, I: $0.048 \mathrm{~g}$ of Copowder was dispersed in $3 \mathrm{ml}$ deionised water. To this, $0.272 \mathrm{~g}$ of $\mathrm{H}_{3} \mathrm{PO}_{3}$ and $0.259 \mathrm{~g}$ of $4,4^{\prime}$-bipyridine were added and the mixture was stirred at room temperature for $30 \mathrm{~min}$. The final mixture with the composition, $1.0 \mathrm{Co}: 4 \mathrm{H}_{3} \mathrm{PO}_{3}: 2\left(4,4^{\prime}\right.$-bipyridine) : $200 \mathrm{H}_{2} \mathrm{O}$, was heated at $125^{\circ} \mathrm{C}$ for 7 days in a $7-\mathrm{ml}$ PTFE-lined acid digestion bomb, to result in large quantities of pink-coloured crystals. The initial $\mathrm{pH}$ was $\sim 2$ and there was no appreciable change in $\mathrm{pH}$ during the reaction.

$2.1 \mathrm{~b} \quad\left[\mathrm{C}_{6} \mathrm{H}_{20} \mathrm{~N}_{3}\right]\left[\mathrm{Zn}_{2}\left(\mathrm{AsO}_{4}\right)\left(\mathrm{HAsO}_{4}\right)_{2}\right] \cdot 2 \mathrm{H}_{2} \mathrm{O}, \quad$ II: $0.045 \mathrm{~g}$ of $\mathrm{ZnO}, 0 \cdot 252 \mathrm{~g}$ of $\mathrm{As}_{2} \mathrm{O}_{5}, 0 \cdot 10 \mathrm{ml}$ of acetic acid, and $0.16 \mathrm{ml}$ of 3,3'-diaminodipropyamine (DPTA) were added to a mixture of $1 \mathrm{ml}$ of THF and $2 \mathrm{ml}$ of water The reaction mixture with the composition, $1 \mathrm{ZnO}: 2 \mathrm{As}_{2} \mathrm{O}_{5}: 1 \mathrm{CH}_{3} \mathrm{COOH}: 2$ DPTA : 22 THF : $200 \mathrm{H}_{2} \mathrm{O}$, was heated at $75^{\circ} \mathrm{C}$ for $72 \mathrm{~h}$ followed by at $150^{\circ} \mathrm{C}$ for $24 \mathrm{~h}$ in a $7-\mathrm{ml}$ PTFE-lined acid-digestion bomb, to result in large quantities of colourless crystals. The initial and final $\mathrm{pH}$ values of the reaction mixture were $\sim 4$ and $\sim 3$ respectively.

$2.1 \mathrm{c} \quad\left[\mathrm{H}_{3} \mathrm{NCH}_{2} \mathrm{CH}\left(\mathrm{NH}_{3}\right) \mathrm{CH}_{3}\right]_{3}\left[\mathrm{Fe}_{6}{ }^{\mathrm{III}}\left(\mathrm{HAsO}_{4}\right)_{6}\left(\mathrm{AsO}_{4}\right)_{2}\right.$ $\left(\mathrm{C}_{2} \mathrm{O}_{4}\right)_{3}$ ], III: $0.297 \mathrm{~g}$ of iron(II)oxalate dihydrate was dissolved in $4 \mathrm{ml}$ of millipore water. To this, $1.249 \mathrm{~g}$ of $\mathrm{H}_{3} \mathrm{AsO}_{4}$ and $0.28 \mathrm{ml}$ of 1,2-diaminopropane (1,2-DAP) (99\%) were added and the mixture was homogenized for $30 \mathrm{~min}$. at room temperature. The final mixture with the composition, $1 \cdot 5 \mathrm{FeC}_{2} \mathrm{O}_{4} \cdot 2 \mathrm{H}_{2} \mathrm{O}$ : $8 \mathrm{H}_{3} \mathrm{AsO}_{4}: 3$ (1,2-DAP) : $200 \mathrm{H}_{2} \mathrm{O}$, was heated at $150^{\circ} \mathrm{C}$ for 3 days in a 23-ml PTFE-lined aciddigestion bomb, to result in large quantities of colourless crystals. The initial and final $\mathrm{pH}$ of the reaction mixture was $\sim 2$ and there was no appreciable change in the $\mathrm{pH}$ during the reaction.

2.1d $\left[\mathrm{C}_{5} \mathrm{~N}_{2} \mathrm{H}_{14}\right]\left[\mathrm{Fe}_{4}{ }_{4}\left(\mathrm{HPO}_{3}\right)_{2}\left(\mathrm{C}_{2} \mathrm{O}_{4}\right)_{3}\right], \mathbf{I V}: 0 \cdot 177 \mathrm{~g}$ of Fe-powder was dispersed in $7 \mathrm{ml}$ of deionised water. To this, $0.521 \mathrm{~g}$ of $\mathrm{H}_{3} \mathrm{PO}_{3}, 0.400 \mathrm{~g}$ of oxalic acid and $0.318 \mathrm{~g}$ of homopiperazine were added and the mixture was homogenized for $30 \mathrm{~min}$ at room temperature. The final mixture with the composition, 
1.0 Fe:2.0 $\mathrm{H}_{3} \mathrm{PO}_{3}: 1 \cdot 0$ oxalic acid:1.0 Homopiperazine: $122 \mathrm{H}_{2} \mathrm{O}$, was heated successfully at $125^{\circ} \mathrm{C}$ for $96 \mathrm{~h}, 150^{\circ} \mathrm{C}$ for $48 \mathrm{~h}$ and $180^{\circ} \mathrm{C}$ for $24 \mathrm{~h}$ in a $23-\mathrm{ml}$ teflon-lined acid-digestion bomb to result in mild yellow-coloured crystals. The initial and final $\mathrm{pH}$ of the reaction mixture was $\sim 2$.

$2.1 \mathrm{e} \quad\left\{\mathrm{Gd}\left(\mathrm{H}_{2} \mathrm{O}\right)_{3} \mathrm{Co}\left[\mathrm{C}_{5} \mathrm{~N}_{1} \mathrm{H}_{3}(\mathrm{COO})_{2}\right]_{3}\right\}, \mathbf{V}: 0.343 \mathrm{~g}$ of $\mathrm{Gd}\left(\mathrm{NO}_{3}\right)_{3}$ and $0.251 \mathrm{~g}$ of $\mathrm{Co}(\mathrm{OAc})_{2} \cdot 4 \mathrm{H}_{2} \mathrm{O}$ were dissolved in $14 \mathrm{ml}$ deionised water. To this, $0.337 \mathrm{~g}$ of pyridine-2,3-dicarboxylic acid (Py-2,3-acid) was added and the mixture was homogenized for $30 \mathrm{~min}$ at room temperature. The final mixture with the composition, $1 \mathrm{Gd}\left(\mathrm{NO}_{3}\right)_{3}: 1 \mathrm{Co}(\mathrm{OAc})_{2} \cdot 4 \mathrm{H}_{2} \mathrm{O}: 2(\mathrm{Py}-2,3-$ acid) : $780 \mathrm{H}_{2} \mathrm{O}$, was heated at $140^{\circ} \mathrm{C}$ for $72 \mathrm{~h}$ in a 23-ml PTFE-lined acid-digestion bomb to result in large quantities of pink-coloured crystals.

2.1f $\left\{\mathrm{Zn}\left(\mathrm{H}_{2} \mathrm{O}\right)_{2}\left[\mathrm{C}_{5} \mathrm{~N}_{1} \mathrm{H}_{3}(\mathrm{COO})_{2}\right]\right\} \cdot \mathrm{H}_{2} \mathrm{O}$, VI: $0 \cdot 143 \mathrm{~g}$ of $\mathrm{ZnSO}_{4} \cdot 7 \mathrm{H}_{2} \mathrm{O}$ was dispersed on $3 \mathrm{ml}$ of deionised water. To this, $0.085 \mathrm{~g}$ of pyridine-2,5-dicarboxylic acid (Py-2,5-acid), 0.02g of $\mathrm{NaOH}, 0.079 \mathrm{~g}$ of 4,4'bipyridine and $0.03 \mathrm{ml}$ of triethyl amine (TEA) were added and the mixture was homogenized for $30 \mathrm{~min}$ at room temperature. The final mixture with the composition $0 \cdot 5 \mathrm{ZnSO}_{4} \cdot 7 \mathrm{H}_{2} \mathrm{O}: 0.5$ (Py-2,5-acid) : 0.5 $\mathrm{NaOH}: 0 \cdot 5$ 4,4'-Bipy: 0.25 TEA : $170 \mathrm{H}_{2} \mathrm{O}$ was heated at $150^{\circ} \mathrm{C}$ for $72 \mathrm{~h}$ in a 7 -ml PTFE-lined acid-digestion bomb to result in large quantities of colourless crystals.

In all the cases, the products were filtered under vacuum and washed thoroughly using deionised water and dried at ambient conditions. In most of the cases, the yield of the solid phase product was $\sim 70$ $80 \%$ based on the metal source.

\subsection{Single crystal structure determination}

A suitable single crystal of I-VI was carefully selected and glued to a thin glass fibre. The single-crystal X-ray diffraction data were collected on a Bruker AXS Smart Apex CCD diffractometer at 293(2) K. The X-ray generator was operated at $50 \mathrm{kV}$ and $35 \mathrm{~mA}$ using $\operatorname{MoK} \alpha(\lambda=0.71073 \AA)$ radiation. Data were collected with $\omega$ scans of width $0 \cdot 3^{\circ}$. A total of 606 frames were collected in three different settings of $\varphi\left(0,90,180^{\circ}\right)$ keeping the sample-to-detector distance fixed at $6.03 \mathrm{~cm}$ and the detector position

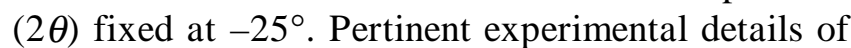
the structure determination of all the compounds are presented in tables 1 and 2 .
The data were reduced using SAINTPLUS, ${ }^{5}$ and an empirical absorption correction was applied using the SADABS program. ${ }^{6}$ The crystal structure was solved and refined using SHELX-97 present in the WinGx suit of program (version 1.63.04a). ${ }^{7}$ The hydrogen atom on the $\mathrm{P}-\mathrm{H}$ group of compound $\mathbf{I}$ and $\mathbf{I V}$ and the hydrogen positions of the amine molecules of I-III compounds were initially located in the difference Fourier map. Due to the disorder of the amine molecules in IV, we have not been able to locate the hydrogen atoms. All the other hydrogen atoms were located in the difference Fourier map and for the final refinement the hydrogen atoms were placed in geometrically ideal positions and refined using the riding mode. The last cycles of refinements included atomic positions, anisotropic thermal parameters for all the non-hydrogen atoms and isotropic thermal parameters for all the hydrogen atoms. Full-matrixleast-squares structure refinement against $|F|^{2}$ was carried out using the WINGX package of programs. ${ }^{8}$

\subsection{Examples of the use of hydrothermal method}

2.3a Simple inorganic network structures: As described above, we have prepared a cobalt phosphite, $\left[\mathrm{Co}^{\mathrm{II}}\left(\mathrm{C}_{10} \mathrm{H}_{8} \mathrm{~N}_{2}\right)\left(\mathrm{H}_{2} \mathrm{PO}_{3}\right)_{2}\right]$, I, and a zinc arsenate, $\left[\mathrm{C}_{6} \mathrm{~N}_{3} \mathrm{H}_{20}\right]\left[\mathrm{Zn}_{2}{ }_{2}\left(\mathrm{AsO}_{4}\right)\left(\mathrm{HAsO}_{4}\right)_{2}\right] \cdot 2 \mathrm{H}_{2} \mathrm{O}$, II, possessing open structures. In the structure of $\mathbf{I}$, there are two $\mathrm{P}$ and one Co atoms in the asymmetric unit that are crystallographically independent. The $\mathrm{Co}(1)$ is octahedrally coordinated to four oxygen atoms and two nitrogen atoms of the 4,4'-bipyridine molecule. One of the oxygen atoms, $[\mathrm{O}(3)]$, is three-coordinated connecting two $\mathrm{Co}$ and a $\mathrm{P}$ centre. The $\mathrm{Co}-\mathrm{O} / \mathrm{N}$ bond distances are in the range of $2 \cdot 052(3)-2 \cdot 197(3) \AA$ $[\mathrm{av} .(\mathrm{Co}-\mathrm{O} / \mathrm{N})=2 \cdot 146 \AA$ ] $]$ and the $\mathrm{O} / \mathrm{N}-\mathrm{Co}-\mathrm{O} / \mathrm{N}$ bond angles are in the range of $80.73(11)-175 \cdot 17(11)^{\circ}$ [av. $(\mathrm{O} / \mathrm{N}-\mathrm{Co}-\mathrm{O} / \mathrm{N})=106 \cdot 74^{\circ}$ ]. The cobalt atom is connected to two distinct phosphorous atoms through Co-O-P bonds. Of the two $\mathrm{P}$ atoms, the $\mathrm{P}(1)$ atom is connected to the cobalt atom via one $\mathrm{P}-\mathrm{O}-\mathrm{Co}$ bond and possess two terminal $\mathrm{P}-\mathrm{O}$ linkages, while $\mathrm{P}(2)$ is connected by two $\mathrm{P}-\mathrm{O}-\mathrm{Co}$ bonds and possesses one terminal $\mathrm{P}-\mathrm{O}$ bond. The $\mathrm{P}-\mathrm{O}$ bond distances are in the range of $1.484(3)-1.550(3) \AA$ [av. $(\mathrm{P}-\mathrm{O})=1.521 \AA$ ] and the $\mathrm{O}-\mathrm{P}-\mathrm{O}$ bond angles are in the range of 107.61 $(16)-117 \cdot 2(15)^{\circ}$ [av. $(\mathrm{O}-\mathrm{P}-\mathrm{O})=111 \cdot 77^{\circ}$ ]. The charge-balancing criterion requires the presence of two protons associated with the $\mathrm{P}-\mathrm{O}$ bonds. Bond valence sum calculations ${ }^{9}$ and bond length consideration indicate that $\mathrm{P}(1)-\mathrm{O}(5)$ with a distance of 
Table 1. Crystal data and structure refinement parameters for $\left[\mathrm{Co}\left(\mathrm{C}_{10} \mathrm{H}_{8} \mathrm{~N}_{2}\right)\left(\mathrm{H}_{2} \mathrm{PO}_{3}\right)_{2}\right], \mathbf{I},\left[\mathrm{C}_{6} \mathrm{~N}_{3} \mathrm{H}_{20}\right]\left[\mathrm{Zn}_{2}{ }_{2}\left(\mathrm{AsO}_{4}\right)\right.$ $\left.\left(\mathrm{HAsO}_{4}\right)_{2}\right] \cdot 2 \mathrm{H}_{2} \mathrm{O}$, II and $\left[\mathrm{NH}_{3}\left(\mathrm{CH}_{2}\right) \mathrm{CH}\left(\mathrm{NH}_{3}\right) \mathrm{CH}_{3}\right]_{3}\left[\mathrm{Fe}_{6}\left(\mathrm{AsO}_{4}\right)_{2}\left(\mathrm{HAsO}_{4}\right)_{6}\left(\mathrm{C}_{2} \mathrm{O}_{4}\right)_{3}\right]$, III.

\begin{tabular}{|c|c|c|c|}
\hline Structure parameters & $\mathbf{I}$ & II & III \\
\hline Empirical formula & $\mathrm{CoP}_{2} \mathrm{~N}_{2} \mathrm{O}_{6} \mathrm{C}_{10} \mathrm{H}_{12}$ & $\mathrm{Zn}_{2} \mathrm{As}_{3} \mathrm{O}_{14} \mathrm{~N}_{2} \mathrm{C}_{6} \mathrm{H}_{26}$ & $\mathrm{C}_{15} \mathrm{H}_{42} \mathrm{As}_{8} \mathrm{Fe}_{6} \mathrm{~N}_{6} \mathrm{O}_{44}$ \\
\hline Formula weight & 377.093 & $719 \cdot 80$ & 1944.96 \\
\hline Crystal system & Monoclinic & Triclinic & Trigonal \\
\hline Space group & $C 2 / c($ no. 15$)$ & $P(-1)($ no. 2$)$ & $P-3 c 1($ no. 165$)$ \\
\hline$a(\AA)$ & $17 \cdot 2718(6)$ & $8 \cdot 5248(2)$ & $13 \cdot 9899(12)$ \\
\hline$b(\AA)$ & $11 \cdot 4561(4)$ & $8 \cdot 76270(10)$ & $13 \cdot 9899(12)$ \\
\hline$c(\AA)$ & $16 \cdot 9932(5)$ & $14 \cdot 08270(10)$ & $14 \cdot 936(3)$ \\
\hline$\alpha\left(^{\circ}\right)$ & $90 \cdot 000$ & $98 \cdot 5260(10)$ & $90 \cdot 0$ \\
\hline$\beta\left(^{\circ}\right)$ & $119 \cdot 014(10)$ & $90 \cdot 7420(10)$ & $90 \cdot 0$ \\
\hline$\gamma\left({ }^{\circ}\right)$ & $90 \cdot 000$ & $101 \cdot 8540(10)$ & $120 \cdot 0$ \\
\hline Volume $\left(\AA^{3}\right)$ & $2940 \cdot 4(2)$ & $1017 \cdot 14(3)$ & $2531 \cdot 6(5)$ \\
\hline$Z$ & 8 & 2 & 12 \\
\hline$T(\mathrm{~K})$ & $293(2)$ & $293(2)$ & $2 \cdot 548$ \\
\hline$\rho_{\text {calc }}\left(\mathrm{mg} \mathrm{m}^{-3}\right)$ & $1 \cdot 704$ & $2 \cdot 350$ & $6 \cdot 987$ \\
\hline$\mu\left(\mathrm{mm}^{-1}\right)$ & $1 \cdot 411$ & $7 \cdot 271$ & $0 \cdot 71073$ \\
\hline$\theta$ range $(\mathrm{deg})$ & $2 \cdot 23$ to $23 \cdot 29^{\circ}$ & $1 \cdot 46$ to $23 \cdot 32$ & 1886 \\
\hline$\lambda\left(\mathrm{MoK}_{\alpha}\right)(\mathrm{A})$ & $0 \cdot 71073$ & $0 \cdot 71073$ & $2 \cdot 73-27 \cdot 94$ \\
\hline Reflection collected & 6037 & 2936 & 20858 \\
\hline Unique reflections & 2119 & 1057 & 2032 \\
\hline Number of parameters & 191 & 271 & 1835 \\
\hline Goodness of fit $\left(S_{\mathrm{obs}}\right)$ & $1 \cdot 083$ & $0 \cdot 251$ & $0 \cdot 0335$ \\
\hline$R$ index $[I>2 \sigma(I)]$ & $R_{1}=0.0423, w R_{2}=0.1189$ & $R_{1}=0 \cdot 0396, w R_{2}=\cdot 0926$ & $R_{1}=0.0323^{\mathrm{a}} ; w R_{2}=0.0914^{\mathrm{b}}$ \\
\hline$R$ (all data) & $R_{1}=0 \cdot 0453, w R_{2}=0 \cdot 1229$ & $R_{1}=0 \cdot 0649, w R_{2}=0 \cdot 1254$ & $R_{1}=0.0365^{\mathrm{a}} ; w R_{2}=0.0938^{\mathrm{b}}$ \\
\hline $\begin{array}{l}\text { Largest diff } \cdot \text { peak } \\
\text { and hole } \AA^{-3}\end{array}$ & 0.787 and $-0.533 \mathrm{e}^{-3}$ & 1.043 and $-0.788 \mathrm{e}^{-3}$ & $1 \cdot 019$ and -1.302 \\
\hline
\end{tabular}

$1 \cdot 553(3) \AA$ and $\mathrm{P}(2)-\mathrm{O}(6)$ with a distance of $1.556(3) \AA$ are protonated. Thus, the phosphite groups are actually $\mathrm{H}_{2} \mathrm{PO}_{3}$ units. The selected bond distances are presented in table 3.

The structure of $\mathbf{I}$ consists of a network of $\mathrm{CoO}_{4} \mathrm{~N}_{2}$ octahedra and $\mathrm{H}_{2} \mathrm{P}(2) \mathrm{O}_{3}$ units. The Co octahedra share two oxygen atoms, $[\mathrm{O}(3)]$, forming an edgeshared dimer, $\mathrm{Co}_{2} \mathrm{O}_{6} \mathrm{~N}_{4}$. This dimer units are connected through their vertices with the $\mathrm{H}_{2} \mathrm{P}(2) \mathrm{O}_{3}$ units giving rise to four-membered rings, which are connected together forming a one-dimensional ladderlike chain structure (figure 1a). The $\mathrm{H}_{2} \mathrm{P}(1) \mathrm{O}_{3}$ units bond with the one-dimensional chains through the three-coordinated oxygen, $\mathrm{O}(3)$, atom. To our knowledge, a one-dimensional chain of this type has not been observed before. The one-dimensional ladderlike chains are connected by $4,4^{\prime}$-bipyridine ligands forming a two-dimensional layered structure (figure $1 b)$. The connectivity involving the $4,4^{\prime}$-bipyridine has been known in the literature. ${ }^{10-12}$
The structure of zinc arsenate, $\left[\mathrm{C}_{6} \mathrm{~N}_{3} \mathrm{H}_{20}\right]$ $\left[\mathrm{Zn}_{2}{ }_{2}\left(\mathrm{AsO}_{4}\right)\left(\mathrm{HAsO}_{4}\right)_{2}\right] \cdot 2 \mathrm{H}_{2} \mathrm{O}$, II consists of a network of $\mathrm{ZnO}_{4}$ and $\mathrm{AsO}_{3}(\mathrm{OH})$ tetrahedral units, linked together giving rise to a two-dimensional structure. The zinc atoms are tetrahedrally coordinated by oxygen atom neighbours with an average $\mathrm{Zn}-\mathrm{O}$ bond lengths $1.946 \AA$ and $\mathrm{O}-\mathrm{Zn}-\mathrm{O}$ bond angles are in the range $97 \cdot 0(3)-119 \cdot 8(3)^{\circ}$ [av. O-Zn-O bond angle $=109 \cdot 3^{\circ}$ ]. The $\mathrm{Zn}$ atoms are connected to the As atoms by $\mathrm{Zn}-$ $\mathrm{O}-$ As linkages with an average $\mathrm{Zn}-\mathrm{O}-\mathrm{As}$ bond angles of $127 \cdot 17^{\circ}$. Of the three arsenic atoms, As(2) and As(3) make three As-O-Zn bonds and posses as one terminal linkage, and As(1) makes four As-O-Zn bonds. The As-O distances are in the range 1.651(6)$1.711(6) \AA$ [av. As $(1)-\mathrm{O}=1.68 \AA]$ and $\mathrm{O}-\mathrm{As}-\mathrm{O}$ bond angles have an average value of $109 \cdot 4^{\circ}$. The terminal $\mathrm{As}(1)-\mathrm{O}(4)$ and $\mathrm{As}(2)-\mathrm{O}(8)$ bonds with distances of 1.723 and $1.688 \AA$ respectively, are $-\mathrm{OH}$ groups. The total negative charge on the framework of -3 is balanced by the presence of one fully protonated 
Table 2. Crystal data and structure refinement parameters for $\left[\mathrm{C}_{5} \mathrm{~N}_{2} \mathrm{H}_{14}\right]\left[\mathrm{Fe}_{4}{ }_{4}{ }_{4}\left(\mathrm{HPO}_{3}\right)_{2}\left(\mathrm{C}_{2} \mathrm{O}_{4}\right)_{3}\right], \mathbf{I V},\left\{\mathrm{Gd}\left(\mathrm{H}_{2} \mathrm{O}\right)_{3}\right.$ $\left.\mathrm{Co}\left[\mathrm{C}_{5} \mathrm{~N}_{1} \mathrm{H}_{3}(\mathrm{COO})_{2}\right]_{3}\right\}, \mathbf{V}$ and $\left\{\mathrm{Zn}\left(\mathrm{H}_{2} \mathrm{O}\right)_{2}\left[\mathrm{C}_{5} \mathrm{~N}_{1} \mathrm{H}_{3}(\mathrm{COO})_{2}\right]\right\} \cdot \mathrm{H}_{2} \mathrm{O}$, VI.

\begin{tabular}{|c|c|c|c|}
\hline Structure parameters & IV & $\mathbf{V}$ & VI \\
\hline Empirical formula & $\mathrm{C}_{11} \mathrm{H}_{16} \mathrm{~N}_{2} \mathrm{O}_{18} \mathrm{P}_{2} \mathrm{Fe}$ & $\mathrm{C}_{21} \mathrm{H}_{15} \mathrm{~N}_{3} \mathrm{O}_{15} \mathrm{GdCo}$ & $\mathrm{C}_{7} \mathrm{H}_{9} \mathrm{NO}_{7} \mathrm{Zn}$ \\
\hline Formula weight & $749 \cdot 570$ & $765 \cdot 18$ & $284 \cdot 52$ \\
\hline Crystal system & Monoclinic & Trigonal & Orthorhombic \\
\hline Space group & $P 2(1) / c($ no. 14$)$ & $P 3$ (no. 143) & $P 2_{1} 2_{1} 2_{1}($ no. 19) \\
\hline$a(\AA)$ & $7 \cdot 682$ & $13 \cdot 1879(2)$ & $7 \cdot 3450(7)$ \\
\hline$b(\AA)$ & $7 \cdot 726$ & $13 \cdot 1879(2)$ & $9 \cdot 4412(10)$ \\
\hline$c(\AA)$ & $18 \cdot 092$ & $5 \cdot 9291(10)$ & $13 \cdot 8459(14)$ \\
\hline$\alpha\left(^{\circ}\right)$ & $90 \cdot 000$ & $90 \cdot 000$ & $90 \cdot 000$ \\
\hline$\beta\left(^{\circ}\right)$ & $94 \cdot 443(2)$ & $90 \cdot 000$ & $90 \cdot 000$ \\
\hline$\gamma\left({ }^{\circ}\right)$ & $90 \cdot 000$ & $120 \cdot 000$ & $90 \cdot 000$ \\
\hline Volume $\left(\AA^{3}\right)$ & $1070 \cdot 8(3)$ & $893 \cdot 04(2)$ & $960 \cdot 15(17)$ \\
\hline$Z$ & 4 & 1 & 4 \\
\hline$T(\mathrm{~K})$ & 293(2) & 293(2) & 293(2) \\
\hline$\rho_{\text {calc }}\left(\mathrm{mg} \mathrm{m}^{-3}\right)$ & $2 \cdot 004$ & 1.412 & 1.968 \\
\hline$\mu\left(\mathrm{mm}^{-1}\right)$ & $1 \cdot 589$ & $2 \cdot 363$ & $2 \cdot 580$ \\
\hline$\theta$ range $(\mathrm{deg})$ & $2 \cdot 26$ to $27 \cdot 99$ & $1 \cdot 78$ to $23 \cdot 32$ & $2 \cdot 61$ to $20 \cdot 81$ \\
\hline$\lambda\left(\mathrm{MoK}_{\alpha}\right)(\mathrm{A})$ & $0 \cdot 71073$ & $0 \cdot 71073$ & $0 \cdot 71073$ \\
\hline Reflection collected & 8974 & 3745 & 4672 \\
\hline Unique reflections & 2538 & 1689 & 1005 \\
\hline Number of parameters & 172 & 126 & 153 \\
\hline Goodness of fit (Sobs) & $1 \cdot 053$ & $1 \cdot 142$ & $1 \cdot 107$ \\
\hline$R$ index $[\mathrm{I}>2 \sigma(I)]$ & $R_{1}=0.0376, w R_{2}=0.0993$ & $R_{1}=0.0378, w R_{2}=0.1050$ & $R_{1}=0.0132,{ }^{\mathrm{a}} w R_{2}=0.0361^{\mathrm{b}}$ \\
\hline$R$ (all data) & $R_{1}=0 \cdot 0394, w R_{2}=0 \cdot 1006$ & $R_{1}=0 \cdot 0402, w R_{2}=0 \cdot 1067$ & $R_{1}=0.0132, \mathrm{wR}_{2}=0.0362$ \\
\hline $\begin{array}{l}\text { Largest diff. peak } \\
\text { and hole } \mathrm{e}^{-3}\end{array}$ & 1.740 and -0.892 & 0.963 and -0.756 & $0 \cdot 364$ and $-0 \cdot 166$ \\
\hline
\end{tabular}

3,3'-diaminodipropylamine (DPTA) molecule. Selected bond distances are listed in table 3.

The structure is formed by strictly alternating $\mathrm{ZnO}_{4}$ and $\mathrm{AsO}_{3}(\mathrm{OH})$ tetrahedral units, connected through their vertices forming one-dimensional ladder-like structure. The one-dimensional ladders are further bonded through the four-membered rings giving rise to a layer structure with apertures bound by 8 -T atoms $(\mathrm{T}=\mathrm{Zn}, \mathrm{As})$. The tetrahedral $\mathrm{AsO}_{3}(\mathrm{OH})$ groups, which are bonded to the $\mathrm{Zn}$ atom, hang from the layer and protrude into the inter-lamellar region within which the protonated amine molecules also reside (figure 2). Similar structural arrangements have been observed in open-framework zinc phosphate structures. ${ }^{13}$ The protonated organic amine molecules along with the lattice water molecules are located in the interlamellar region as shown in figure 3. Multipoint hydrogen bonding is important in low-dimensional solids for the structural stability. Since the compounds contains pendant $\mathrm{As}-\mathrm{OH}$ and $\mathrm{As}=\mathrm{O}$ bonds, they can participate in hydrogen-bond interactions. Large number of hydrogen bonds involving organic amine, lattice water and framework oxygen atoms have been observed in II.

\section{3b Inorganic-organic hybrid network structures:} As part of our continuing search for new materials with novel structures, we have also prepared compounds containing two different anions, one derived purely from an inorganic source and the other from organic. Thus, we have compounds containing oxalate units as part of the network along with phosphite and arsenate anions. The structure of the iron oxalate-arsenate, $\quad\left[\mathrm{NH}_{3}\left(\mathrm{CH}_{2}\right) \mathrm{CH}\left(\mathrm{NH}_{3}\right) \mathrm{CH}_{3}\right]_{3}$ $\left[\mathrm{Fe}_{6}\left(\mathrm{AsO}_{4}\right)_{2}\left(\mathrm{HAsO}_{4}\right)_{6}\left(\mathrm{C}_{2} \mathrm{O}_{4}\right)_{3}\right]$, III, consists of a network of $\mathrm{FeO}_{6}$ octahedral, $\mathrm{AsO}_{4}$ tetrahedral and $\mathrm{C}_{2} \mathrm{O}_{4}$ units linked together giving rise to a three-dimensional structure. The Fe atoms are coordinated to six oxygen atom neighbours with four short and two longer $\mathrm{Fe}-$ $\mathrm{O}$ distances. The $\mathrm{Fe}-\mathrm{O}$ distances are in the range 1.929(3)-2.145(3) $\AA$ (av. 2.018 ), the shorter distances corresponding to the $\mathrm{Fe}-\mathrm{O}-\mathrm{As}$ and the longer 
Table 3. Selected bond distances in $\left[\mathrm{Co}^{\mathrm{II}}\left(\mathrm{C}_{10} \mathrm{H}_{8} \mathrm{~N}_{2}\right) \quad\left(\mathrm{H}_{2} \mathrm{PO}_{3}\right)_{2}\right], \quad \mathbf{I}, \quad\left[\mathrm{C}_{6} \mathrm{~N}_{3} \mathrm{H}_{20}\right]$ $\left[\mathrm{Zn}_{2}\left(\mathrm{AsO}_{4}\right)\left(\mathrm{HAsO}_{4}\right)_{2}\right] \cdot 2 \mathrm{H}_{2} \mathrm{O}, \mathbf{I I},\left[\mathrm{NH}_{3}\left(\mathrm{CH}_{2}\right) \mathrm{CH}\left(\mathrm{NH}_{3}\right) \mathrm{CH}_{3}\right]_{3}\left[\mathrm{Fe}_{6}\left(\mathrm{AsO}_{4}\right)_{2}\left(\mathrm{HAsO}_{4}\right)_{6}\left(\mathrm{C}_{2} \mathrm{O}_{4}\right)_{3}\right]$,

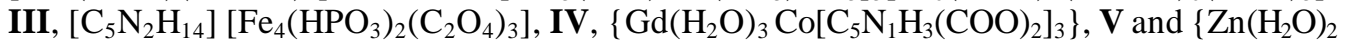
$\left.\left[\mathrm{C}_{5} \mathrm{~N}_{1} \mathrm{H}_{3}(\mathrm{COO})_{2}\right]\right\} \cdot \mathrm{H}_{2} \mathrm{O}$, VI.

\begin{tabular}{|c|c|c|c|}
\hline \multicolumn{4}{|l|}{ Compound I } \\
\hline $\mathrm{Co}(1)-\mathrm{O}(1)$ & $2 \cdot 052(3)$ & $\mathrm{P}(1)-\mathrm{O}(4)$ & $1 \cdot 484(3)$ \\
\hline $\mathrm{Co}(1)-\mathrm{O}(3)^{\# 1}$ & $2 \cdot 158(3)$ & $\mathrm{P}(1)-\mathrm{O}(5)$ & $1 \cdot 553(3)$ \\
\hline $\mathrm{Co}(1)-\mathrm{O}(2)$ & $2 \cdot 112(3)$ & $\mathrm{P}(1)-\mathrm{O}(3)$ & $1 \cdot 532(3)$ \\
\hline $\mathrm{Co}(1)-\mathrm{O}(3)$ & $2 \cdot 176(3)$ & $\mathrm{P}(2)-\mathrm{O}(1)^{\# 2}$ & $1 \cdot 493(3)$ \\
\hline $\mathrm{Co}(1)-\mathrm{N}(1)$ & $2 \cdot 181(3)$ & $\mathrm{P}(2)-\mathrm{O}(2)$ & $1 \cdot 513(3)$ \\
\hline $\mathrm{Co}(1)-\mathrm{N}(2)$ & $2 \cdot 197(3)$ & $\mathrm{P}(2)-\mathrm{O}(6)$ & $1 \cdot 556(3)$ \\
\hline \multicolumn{4}{|l|}{ Compound II } \\
\hline $\operatorname{As}(1)-\mathrm{O}(1)$ & $1 \cdot 653(6)$ & $\operatorname{As}(3)-\mathrm{O}(11)$ & $1 \cdot 688(6)$ \\
\hline $\operatorname{As}(1)-\mathrm{O}(2)$ & $1 \cdot 668(6)$ & $\operatorname{As}(3)-\mathrm{O}(12)$ & $1 \cdot 683(6)$ \\
\hline $\operatorname{As}(1)-\mathrm{O}(3)$ & $1 \cdot 677(6)$ & $\mathrm{Zn}(1)-\mathrm{O}(5)^{\# 3}$ & $1 \cdot 975(6)$ \\
\hline $\operatorname{As}(1)-\mathrm{O}(4)$ & $1 \cdot 723(6)$ & $\mathrm{Zn}(1)-\mathrm{O}(6)^{\# 1}$ & $1 \cdot 929(6)$ \\
\hline $\operatorname{As}(2)-\mathrm{O}(5)$ & $1 \cdot 666(6)$ & $\mathrm{Zn}(1)-\mathrm{O}(9)$ & $1 \cdot 965(6)$ \\
\hline $\operatorname{As}(2)-\mathrm{O}(6)$ & $1 \cdot 671(6)$ & $\mathrm{Zn}(1)-\mathrm{O}(11)^{\# 2}$ & $1 \cdot 942(6)$ \\
\hline $\operatorname{As}(2)-\mathrm{O}(7)$ & $1 \cdot 687(6)$ & $\mathrm{Zn}(2)-\mathrm{O}(2)$ & $1 \cdot 949(6)$ \\
\hline $\operatorname{As}(2)-\mathrm{O}(8)$ & $1 \cdot 688(6)$ & $\mathrm{Zn}(2)-\mathrm{O}(7)$ & $1 \cdot 925(6)$ \\
\hline $\operatorname{As}(3)-\mathrm{O}(9)$ & $1 \cdot 676(6)$ & $\mathrm{Zn}(2)-\mathrm{O}(10)$ & $1.952(6)$ \\
\hline $\operatorname{As}(3)-\mathrm{O}(10)$ & $1 \cdot 674(6)$ & $\mathrm{Zn}(2)-\mathrm{O}(12)^{\# 4}$ & $1 \cdot 930(6)$ \\
\hline \multicolumn{4}{|l|}{ Compound III } \\
\hline $\operatorname{As}(1)-\mathrm{O}(1)$ & $1 \cdot 664(3)$ & $\mathrm{Fe}(1)-\mathrm{O}(1)$ & $1 \cdot 929(3)$ \\
\hline $\operatorname{As}(1)-\mathrm{O}(2)$ & $1 \cdot 668(3)$ & $\mathrm{Fe}(1)-\mathrm{O}(5)$ & $1 \cdot 951(3)$ \\
\hline $\operatorname{As}(1)-\mathrm{O}(3)$ & $1 \cdot 678(3)$ & $\mathrm{Fe}(1)-\mathrm{O}(3)^{\# 2}$ & $1.951(3)$ \\
\hline $\mathrm{As}(1)-\mathrm{O}(4)$ & $1 \cdot 717(3)$ & $\mathrm{Fe}(1)-\mathrm{O}(2)^{\# 3}$ & $1 \cdot 994(3)$ \\
\hline $\operatorname{As}(2)-O(5)^{\# 1}$ & $1 \cdot 673(3)$ & $\mathrm{Fe}(1)-\mathrm{O}(7)$ & $2 \cdot 133(3)$ \\
\hline $\mathrm{As}(2)-\mathrm{O}(5)$ & $1 \cdot 673(3)$ & $\mathrm{Fe}(1)-\mathrm{O}(8)$ & $2 \cdot 145(3)$ \\
\hline $\operatorname{As}(2)-\mathrm{O}(5)^{\# 2}$ & $1 \cdot 673(3)$ & $\mathrm{C}(1)-\mathrm{O}(7)^{\# 4}$ & $1 \cdot 256(3)$ \\
\hline \multirow[t]{2}{*}{$\operatorname{As}(2)-0(6)$} & $1 \cdot 715(4)$ & $\mathrm{C}(2)-\mathrm{O}(8)^{\# 4}$ & $1 \cdot 253(4)$ \\
\hline & & $\mathrm{C}(1)-\mathrm{C}(2)$ & $1 \cdot 536(7)$ \\
\hline \multicolumn{4}{|l|}{ Compound IV } \\
\hline $\mathrm{Fe}(1)-\mathrm{O}(1)$ & $1 \cdot 994(2)$ & $\mathrm{Fe}(2)-\mathrm{O}(8)^{\# 2}$ & $2 \cdot 100(2)$ \\
\hline $\mathrm{Fe}(1)-\mathrm{O}(2)$ & $2 \cdot 088(2)$ & $\mathrm{Fe}(2)-\mathrm{O}(4)$ & $2 \cdot 105(2)$ \\
\hline $\mathrm{Fe}(1)-\mathrm{O}(3)$ & $2 \cdot 106(2)$ & $\mathrm{Fe}(2)-\mathrm{O}(9)^{\# 2}$ & $2 \cdot 153(2)$ \\
\hline $\mathrm{Fe}(1)-\mathrm{O}(4)$ & $2 \cdot 118(2)$ & $\mathrm{Fe}(2)-\mathrm{O}(3)$ & $2 \cdot 239(2)$ \\
\hline $\mathrm{Fe}(1)-\mathrm{O}(5)$ & $2 \cdot 220(2)$ & $\mathrm{P}(1)-\mathrm{O}(7)$ & $1 \cdot 508(2)$ \\
\hline $\mathrm{Fe}(1)-\mathrm{O}(6)$ & $2 \cdot 260(2)$ & $\mathrm{P}(1)-\mathrm{O}(1)$ & $1 \cdot 521(2)$ \\
\hline $\mathrm{Fe}(2)-\mathrm{O}(7) \# 1$ & $1 \cdot 980(2)$ & $\mathrm{P}(1)-\mathrm{O}(4)^{\# 3}$ & $1 \cdot 531(2)$ \\
\hline \multicolumn{4}{|l|}{ Compound $\boldsymbol{V}$} \\
\hline $\mathrm{Gd}(1)-\mathrm{O}(1)^{\# 1}$ & $2 \cdot 406(7)$ & $\mathrm{Gd}(1)-\mathrm{O}(3)^{\# 1}$ & $2 \cdot 504(6)$ \\
\hline $\mathrm{Gd}(1)-\mathrm{O}(1)$ & $2 \cdot 406(7)$ & $\mathrm{Co}(1)-\mathrm{O}(4)$ & $1 \cdot 884(6)$ \\
\hline $\mathrm{Gd}(1)-\mathrm{O}(1)^{\# 2}$ & $2 \cdot 406(7)$ & $\mathrm{Co}(1)-\mathrm{O}(4)^{\# 3}$ & $1 \cdot 884(6)$ \\
\hline $\mathrm{Gd}(1)-\mathrm{O}(2)^{\# 2}$ & $2 \cdot 450(6)$ & $\mathrm{Co}(2)-\mathrm{O}(4)^{\# 4}$ & $1 \cdot 884(6)$ \\
\hline $\mathrm{Gd}(1)-\mathrm{O}(2)$ & $2 \cdot 450(6)$ & $\mathrm{Co}(1)-\mathrm{N}(1)^{\# 3}$ & $1 \cdot 992(7)$ \\
\hline $\mathrm{Gd}(1)-\mathrm{O}(2)^{\# 1}$ & $2 \cdot 450(6)$ & $\mathrm{Co}(1)-\mathrm{N}(1)$ & $1.992(7)$ \\
\hline $\mathrm{Gd}(1)-\mathrm{O}(3)^{\# 2}$ & $2 \cdot 504(6)$ & $\mathrm{Co}(1)-\mathrm{N}(1)^{\# 4}$ & $1 \cdot 992(7)$ \\
\hline $\mathrm{Gd}(1)-\mathrm{O}(3)$ & $2 \cdot 504(6)$ & & \\
\hline \multicolumn{4}{|l|}{ Compound VI } \\
\hline $\mathrm{Zn}(1)-\mathrm{O}(1)$ & $2 \cdot 050(3)$ & $\mathrm{Zn}(1)-\mathrm{O}(4)$ & $2 \cdot 120(3)$ \\
\hline $\mathrm{Zn}(1)-\mathrm{O}(2)$ & $2 \cdot 054(3)$ & $\mathrm{Zn}(1)-\mathrm{N}(1)$ & $2 \cdot 136(3)$ \\
\hline $\mathrm{Zn}(1)-\mathrm{O}(3)$ & $2 \cdot 075(3)$ & $\mathrm{Zn}(1)-\mathrm{O}(5)$ & $2 \cdot 278(3)$ \\
\hline
\end{tabular}

Symmetry transformations used to generate equivalent atoms: $\# 1-x+1, y,-z+1 / 2 ; \# 2-x+1$, $-y+1, z ; \# 3 x, y-1, z ; \# 4 x, y+1, z$ for $\mathbf{I}, \# 1 x-1, y, z ; \# 2-x,-y+1,-z+2 ; \# 3-x+1$, $-y+2,-z+2 ; \# 4-x+1,-y+1,-z+2 ; \# 5 x+1, y, z$ for II, \#1 $-y+1, x-y+1, z$; \#2 $x+y,-x+1, z ; \# 3-x+1,-y+2,-z+1 ; \# 4 x-y+1,-y+2,-z+3 / 2$ for III \# $1 x, y-1, z$; $\# 2 x-1, y, z ; \# 3-x, y+1 / 2,-z+1 / 2$ for $\mathbf{I V}, \# 1-x+y+1,-x+1, z ; \# 2-y+1, x-y, z ; \# 3$ $-x+y,-x, z ; \# 4-y, x-y, z$ for $\mathbf{V}$ 
distances corresponding to the $\mathrm{Fe}-\mathrm{O}-\mathrm{C}$ linkages; these distances are consistent with the iron being in the $3+$ oxidation state. The $\mathrm{O}-\mathrm{Fe}-\mathrm{O}$ bond angles are in the range $87 \cdot 05(11)-174 \cdot 35(12)^{\circ}$. While all the $\mathrm{FeO}_{6}$ vertices are shared with either the As or $\mathrm{C}$ atoms through the oxygen linkages, only three of the vertices of the $\mathrm{AsO}_{4}$ units are shared, the remaining ones being either $\mathrm{As}=\mathrm{O}$ or As- $\mathrm{OH}$ bonds. The As atoms have tetrahedral coordination with As-O distances in the range 1.664(3)-1.717(3) $\AA$ [av. 1.685 $\AA$ for $\mathrm{As}(1)$ and $1.682 \AA$ for As(2), respectively]. The O-As-O bond angles are in the range 105.09(9)-114.80(14) ${ }^{\circ}$ (av. $\left.109 \cdot 3^{\circ}\right)$. The $\mathrm{C}-\mathrm{O}$ bond distances and $\mathrm{O}-\mathrm{C}-\mathrm{O}$ bond angles are in the range expected for this type of bonding. Selected bond distances are given in table 3.

The framework consists of $\mathrm{FeO}_{6}, \mathrm{AsO}_{4}, \mathrm{HAsO}_{4}$ and $\mathrm{C}_{2} \mathrm{O}_{4}$ moieties. Connectivity between the $\mathrm{FeO}_{6}$, $\mathrm{AsO}_{4}$ and $\mathrm{HAsO}_{4}$ polyhedral units leads to an inorganic layer of formula $\left[\mathrm{Fe}_{3}\left(\mathrm{HAsO}_{4}\right)_{3}\left(\mathrm{AsO}_{4}\right)\right]$, with the $\mathrm{FeO}_{6}$ and $\mathrm{AsO}_{4}$ tetrahedra strictly alternating within the
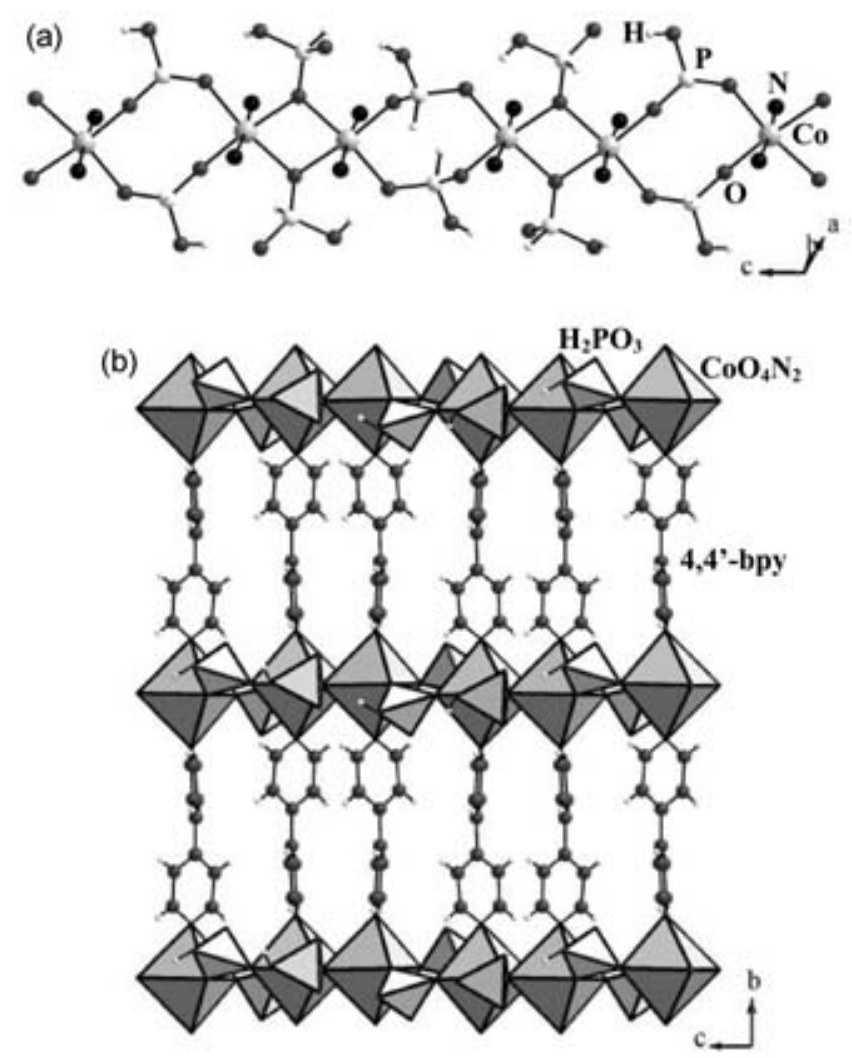

Figure 1. (a) Structure of $\mathbf{I}$, showing the onedimensional ladder-like chains. Note that the $\mathrm{H}_{2} \mathrm{PO}_{3}$ group hangs from the three-coordinated oxygen atoms of the chain. (b) Figure shows the connectivity between the one-dimensional chains and 4,4'-bipyridine units giving rise to a two-dimensional layer. layer. The layers are porous, encompassing a circular 12 -membered ring as shown in figure 4; this layer is topologically identical to that seen in the porous aluminophosphate based upon the $\mathrm{Al}_{3} \mathrm{P}_{4} \mathrm{O}_{16}{ }^{3-}$ ion, with which it shares the same space group, $P-3 c_{1}{ }^{14}$ (note that other layered aluminum phosphates with the $\mathrm{Al}_{3} \mathrm{P}_{4} \mathrm{O}_{16}{ }^{3-}$ stoichiometry are based entirely on tetrahedral nets). ${ }^{15}$ The architecture of III has also been seen in an iron oxalatophosphate. ${ }^{16}$ The 12 -membered pores within the layers are surrounded by 4-membered rings, of which there are two distinct types. In one set of these rings, the arsenic atoms are part of the wall of the 12-membered ring, while in the other an arsenate group caps a six-membered ring and alternates above and below the plane of the inorganic layers (figure 4). The layers are arranged in $A A A A \ldots$ fashion and are held in place by oxalate pillars. The

(a)
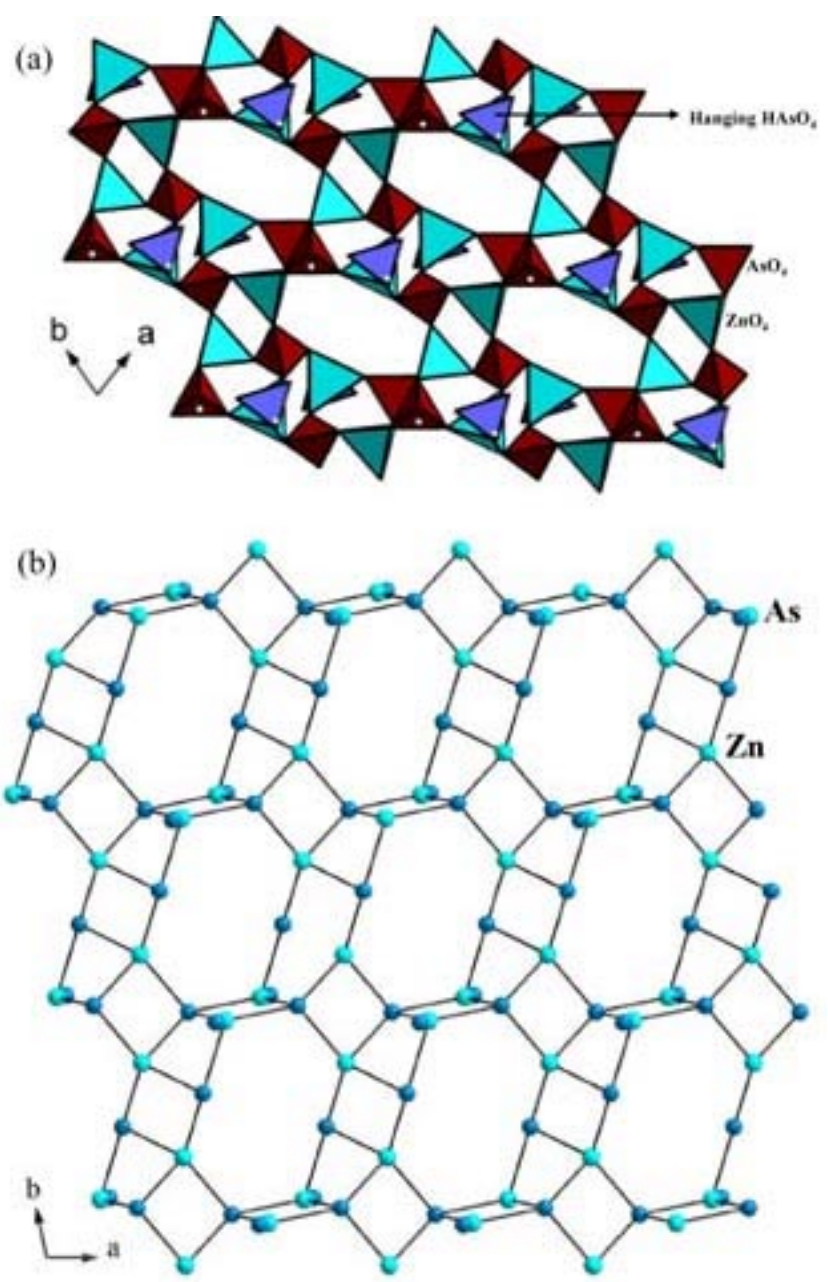

Figure 2. (a) Polyhedral view of the structure of II in the $a b$ plane. Note the presence of the hanging arsenate groups. (b) Figure shows the T-atom $(\mathrm{T}=\mathrm{Zn}, \mathrm{P})$ connectivity within the layer. 
oxalate units are coordinated to the iron centres and connect the adjacent layers (figure 5).

The negative charge of the framework of the iron oxalatoarsenate, III, is compensated by the 1,2-diammoniumpropane cations. Within the structure of III, the porous layers are arranged exactly one over the other, giving rise to a supermesh of apertures. The organic amine molecules, which are disordered in III, occupy the one-dimensional channels that are oriented perpendicular to the inorganic sheets. This results in completely filled channels and no adsorption behaviour was observed. While the structure of III is closely related to that of the iron oxalatophosphate, $\left[\mathrm{NH}_{3}\left(\mathrm{CH}_{2}\right)_{2} \mathrm{NH}_{3}\right]_{3}\left[\mathrm{Fe}_{6}\left(\mathrm{PO}_{4}\right)_{2}\left(\mathrm{HPO}_{4}\right)_{6}\left(\mathrm{C}_{2} \mathrm{O}_{4}\right)_{3}\right]$. $\mathrm{H}_{2} \mathrm{O} \quad(x=3-4)$, reported earlier, ${ }^{16}$ the 1,2 -diaminopropane in III is replaced by ethylenediamine and labile water. The replacement of larger amines by smaller ones plus water has been observed in other systems, such as open framework gallium phosphates. ${ }^{17}$

The asymmetric unit of IV contains 19 non-hydrogen atoms of which two $\mathrm{Fe}$ and one $\mathrm{P}$ atoms are

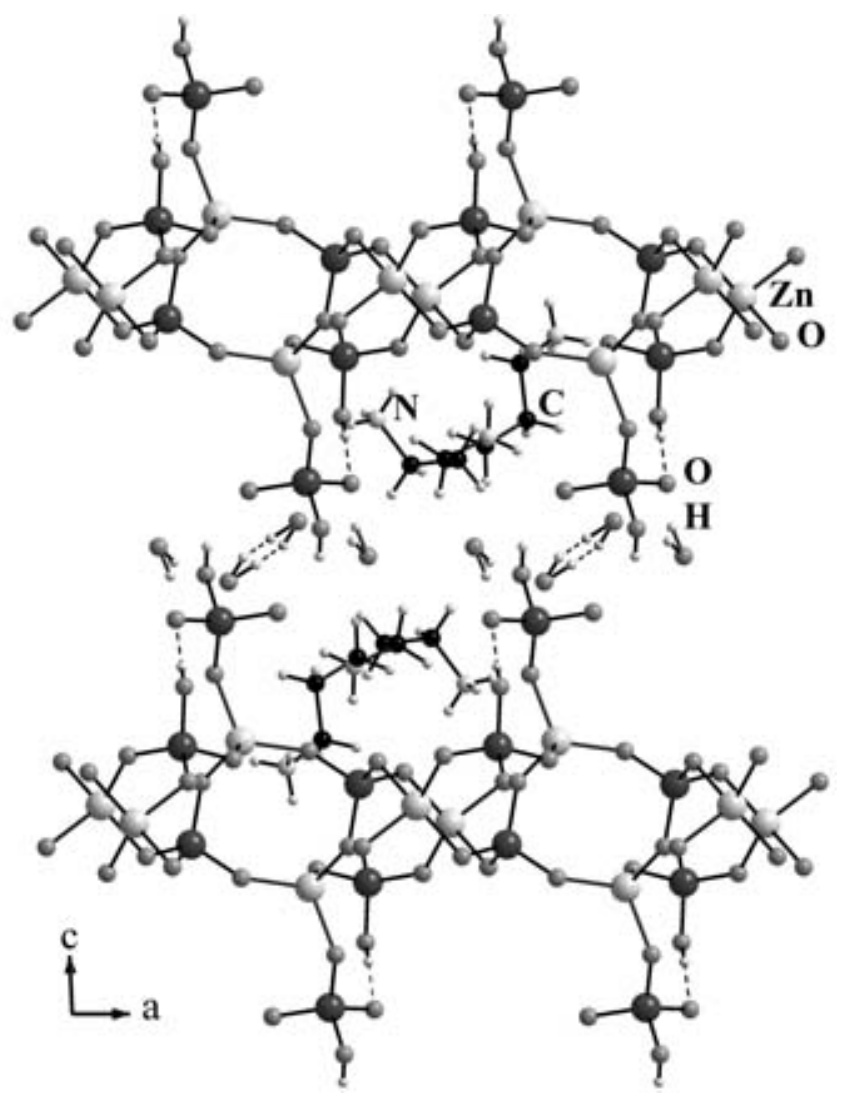

Figure 3. Structure of II in the $a c$ plane showing the arrangement of the layers. Dotted lines represent the possible hydrogen bond interactions. crystallographically independent. The $\mathrm{Fe}(1)$ atoms are octahedrally coordinated with respect to oxygen atoms with average distances of $2 \cdot 131$ and $2 \cdot 115 \AA$ respectively. The $\mathrm{O}-\mathrm{Fe}-\mathrm{O}$ bond angle are in the range 76.48(9)-166.92(9) ${ }^{\circ}$. The iron atoms are connected to a phosphorous atom through $\mathrm{Fe}-\mathrm{O}-\mathrm{P}$ bonds and to oxalate groups through $\mathrm{Fe}-\mathrm{O}-\mathrm{C}$ bonds with average bond angle of 130.42 and $118.16^{\circ}$ respectively. The iron atoms are also connected to each other through three-coordinated oxygen atoms $[\mathrm{O}(3)$ and $\mathrm{O}(4)]$ with average $\mathrm{Fe}-\mathrm{O}-\mathrm{Fe}$ bond angle of $101.07^{\circ}$. The $\mathrm{P}$ atoms are connected to the iron atom via three $\mathrm{Fe}-$ $\mathrm{O}-\mathrm{P}$ bond and possess one terminal $\mathrm{P}-\mathrm{H}$ bond. The $\mathrm{P}-\mathrm{O}$ bond distances are in the range of 1.503(2)$1.531(3) \AA$ [av. $(\mathrm{P}-\mathrm{O})=1.520 \AA$ ] and the $\mathrm{O}-\mathrm{P}-\mathrm{O}$ bond angles are in the range of $110 \cdot 60(13)-112.88(14)^{\circ}$ [av. $(\mathrm{O}-\mathrm{P}-\mathrm{O})=111 \cdot 61^{\circ}$ ].

The structure of IV is built up from a linkage involving the $\mathrm{FeO}_{6}$ octahedra, the $\mathrm{HPO}_{3}$ pseudotetrahedra and the oxalate units. The iron atoms are connected to each other through two three-coordinated oxygen atoms $[\mathrm{O}(3)$ and $\mathrm{O}(4)]$ forming a edge-shared dimer, $\mathrm{Fe}_{2} \mathrm{O}_{10}$, and the dimers are linked through their corners, involving another three-coordinate oxygen atom $[\mathrm{O}(6)]$, giving rise to infinite one-dimensional helical chains of $\mathrm{Fe}-\mathrm{O}-\mathrm{Fe}$ (figure 6a). The phosphite units are grafted to these chains forming a onedimensional structure as shown in figure $6 \mathrm{~b}$. The oxalate moieties bond with the iron centre through in-plane connectivity forming a hybrid layer and by out-of-plane connectivity with the layer to form the

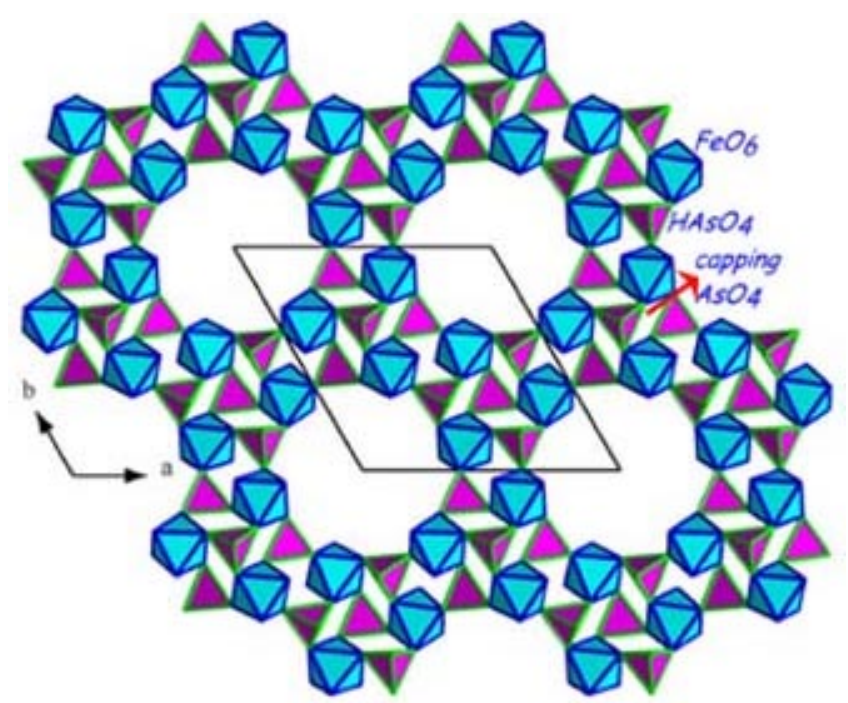

Figure 4. Structure of III in the $a b$ plane showing the 12-membered pore-opening. The amine molecules and the oxalate units are not shown for clarity. 


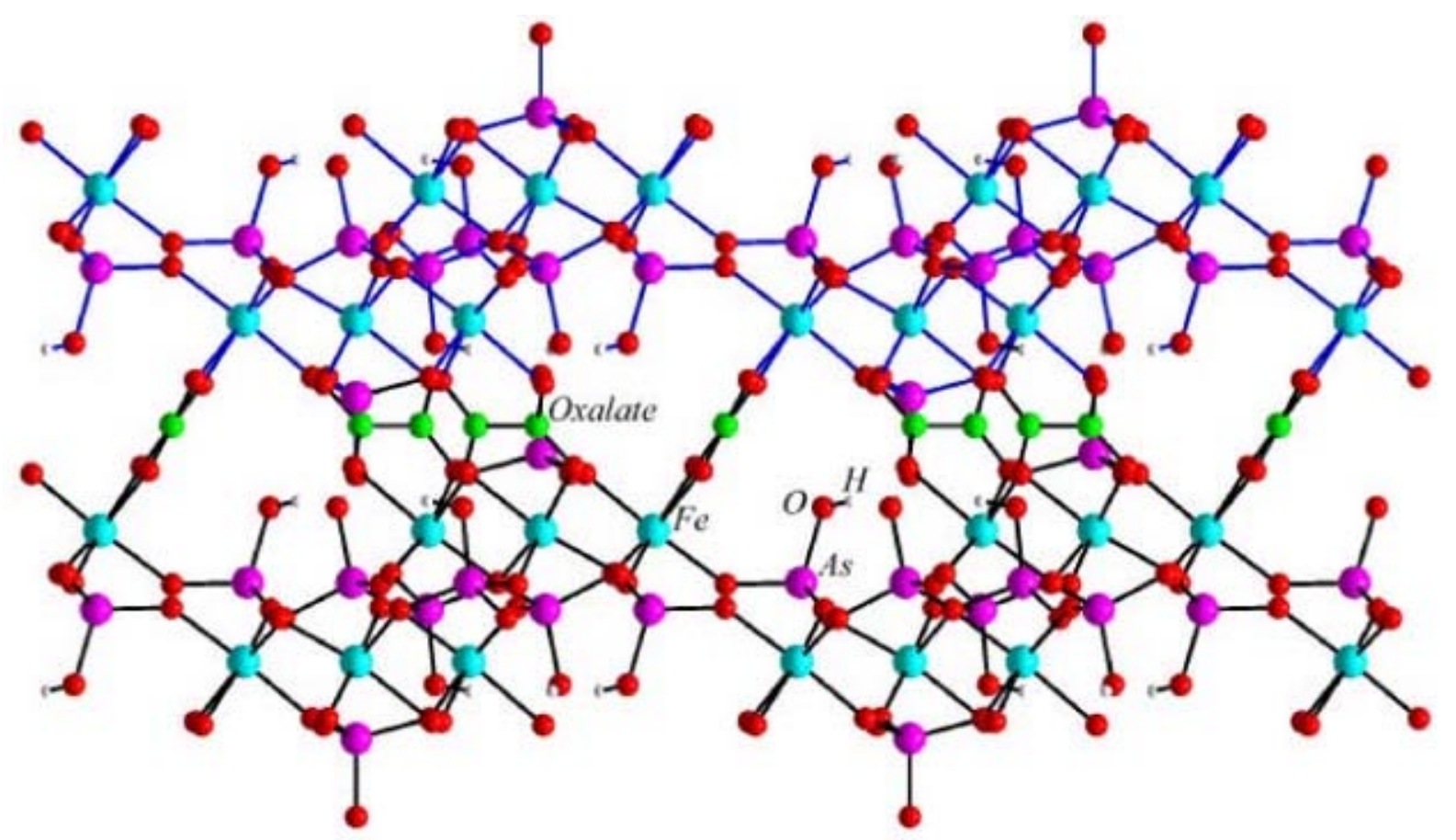

Figure 5. Structure of III viewed perpendicular to the inorganic layers, showing the connectivity between these layers by the oxalate groups.
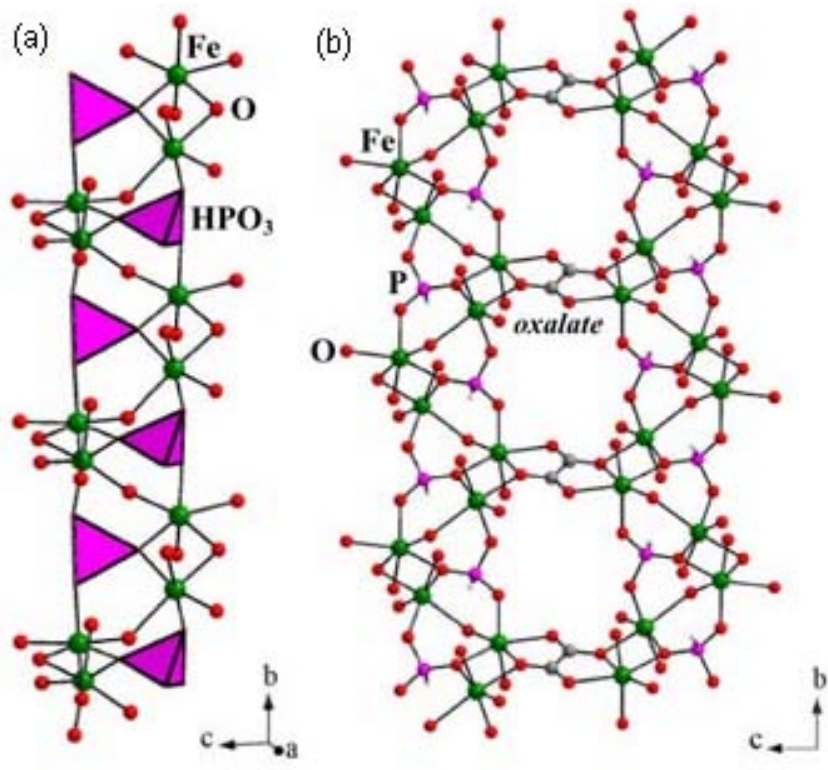

Figure 6. (a) The one-dimensional $\mathrm{Fe}-\mathrm{O}-\mathrm{Fe}$ chain in IV. (b) The one-dimensional structure formed by the linkage between iron and phosphite units. Oxalate units are not shown for clarity.

three-dimensional structure with channels (figure 7). Similar connectivity has been observed before in oxalatephosphite $^{18}$ and oxalatophosphate structures. ${ }^{19}$ The organic amine molecule occupy the middle of the channels formed by this connectivity.

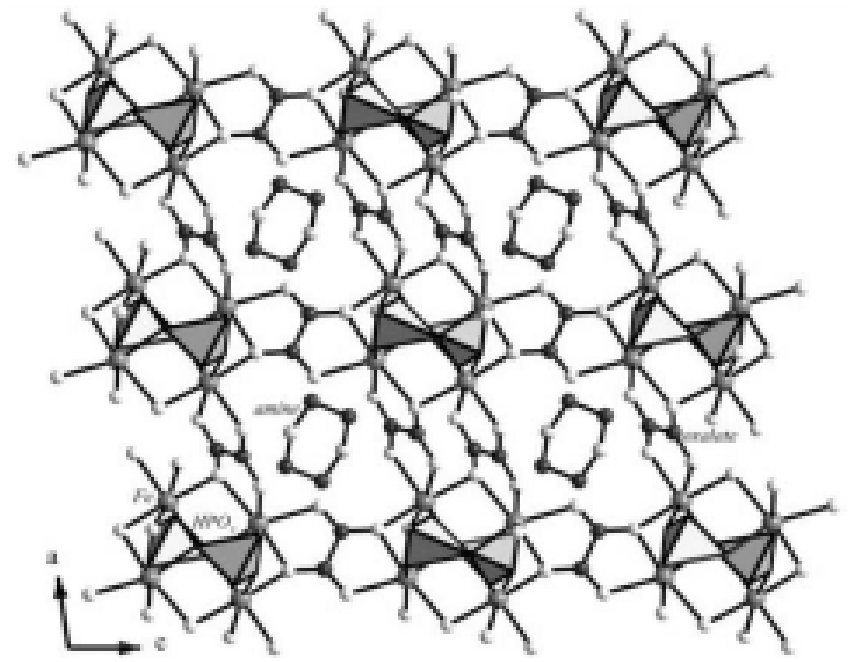

Figure 7. The connectivity between $\mathrm{Fe}$ and oxalate units forming the iron oxalate three-dimensional structure. The piperazine molecules occupy the channels.

From the structural point of view, the structure of IV presents many unique features. The first and foremost is the presence of infinite one-dimensional helical $\mathrm{Fe}-\mathrm{O}-\mathrm{Fe}$ chains. Though infinite $\mathrm{Fe}-\mathrm{O}-\mathrm{Fe}$ chains have been observed before in ironphosphates ${ }^{20}$ such a structural feature has not been commonly observed in inorganic-organic hybrid structures. Secondly, the connectivity between the phosphite 
units and $\mathrm{Fe}-\mathrm{O}-\mathrm{Fe}$ chains give rise to a one-dimensional tancoite-like structure. Tancoite structure has the general formula, $\left[\mathrm{M}\left(\mathrm{TO}_{4}\right)_{2} \varphi\right]_{n}(\mathrm{M}$ is an octahedrally coordinated element, $\mathrm{T}$ is a tetrahedrally coor-

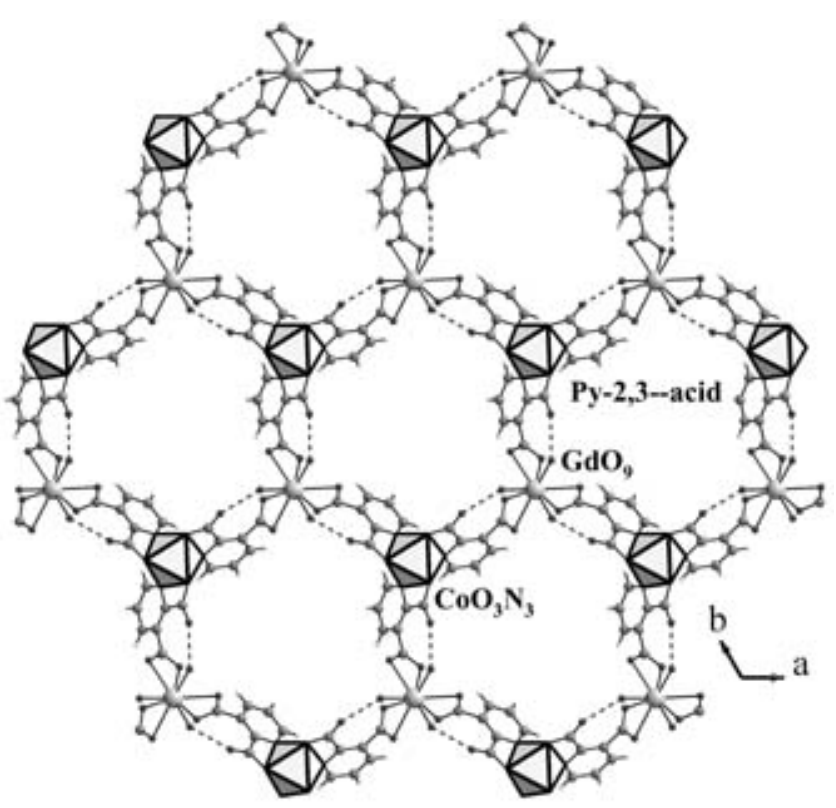

Figure 8. View of the structure of $\mathbf{V}$ in the $a b$ plane showing a single layer. Dotted lines represent possible hydrogen bond interaction. Note that the hydrogen bond interaction creates specific pockets of hybrophilicity within the aperture.

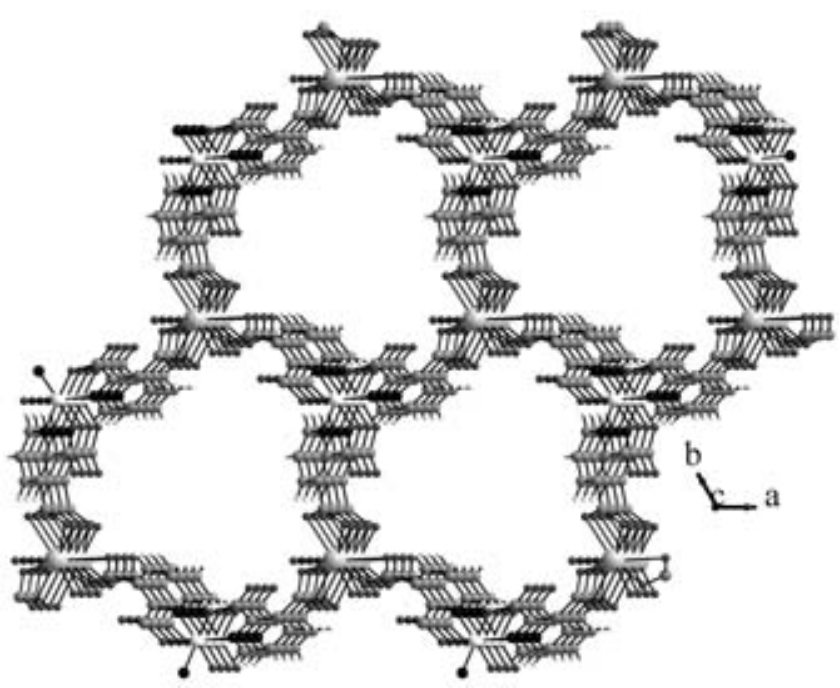

Figure 9. View of the structure of $\mathbf{V}$ showing the arrangement of the layers. Note that the layers are arranged in a $A A A A$... fashion giving rise to a one-dimensional channel. dinated element and $\varphi$ is an anionic ligand; e.g. $\mathrm{O}^{2-}$, $\mathrm{OH}^{-}, \mathrm{F}^{-}$etc.). It has been observed that the onedimensional iron phosphates, in general, form with the tancoite structure. ${ }^{21}$

2.3c Coordination polymer structures: We have prepared mixed metal $(3 d-4 f)$ coordination polymer of the formula, $\left\{\mathrm{Gd}\left(\mathrm{H}_{2} \mathrm{O}\right)_{3} \mathrm{Co}\left[\mathrm{C}_{5} \mathrm{~N}_{1} \mathrm{H}_{3}(\mathrm{COO})_{2}\right]_{3}\right\}, \mathbf{V}$. The asymmetric unit of $\mathbf{V}$ consists 15 non-hydrogen atoms, of which one gadolinium atom and one cobalt atom are crystallographically independent. The $\mathrm{Gd}^{+3}$ and the $\mathrm{Co}^{+3}$ are located in special positions with a site occupancy of $0 \cdot 33$, respectively $\left(\mathrm{Gd}^{+3} \mathrm{oc}-\right.$ cupies the $1 c$ site and $\mathrm{Co}^{+3}$ occupies the $1 a$ site). $\mathrm{Gd}^{+3}$ ions are bonded with nine nearest neighbour oxygen atoms and have a tricapped trigonal prismatic geometry. Of the nine oxygen atoms, three oxygen atoms belong to the terminal water molecules and six to the carboxylate oxygen atoms. The $\mathrm{Co}^{+3}$ ions have an octahedral geometry formed by three carboxylate oxygen atoms and three nitrogen atoms of the pyridine ring. The average distances of $2.45 \AA$ for the $\mathrm{Gd}-\mathrm{O}$ and $1.88 \AA$ and $1.99 \AA$ for the $\mathrm{Co}-\mathrm{O}$ and $\mathrm{Co}-\mathrm{N}$ bonds respectively, result from this connectivity. The $\mathrm{O}-\mathrm{Gd}-\mathrm{O}$ bond angles are in the range $52 \cdot 7(2)-149 \cdot 0(3)^{\circ}$ and the $\mathrm{O} / \mathrm{N}-\mathrm{Co}-\mathrm{O} / \mathrm{N}$ bond angles are in the range $84.5(3)-173 \cdot 8(3)^{\circ}$. The selected bond distances are listed in table 3. There is only one type of pyridine-2,3-dicarboxylate anion present in the structure.

The two carboxylate units of the pyridine-2,3dicarboxylate show differences in the connectivity with respect to the $\mathrm{Gd}^{+3}$ and $\mathrm{Co}^{+3}$ ions - one having a monodentate connectivity with the $\mathrm{Co}^{+3}$ ions and

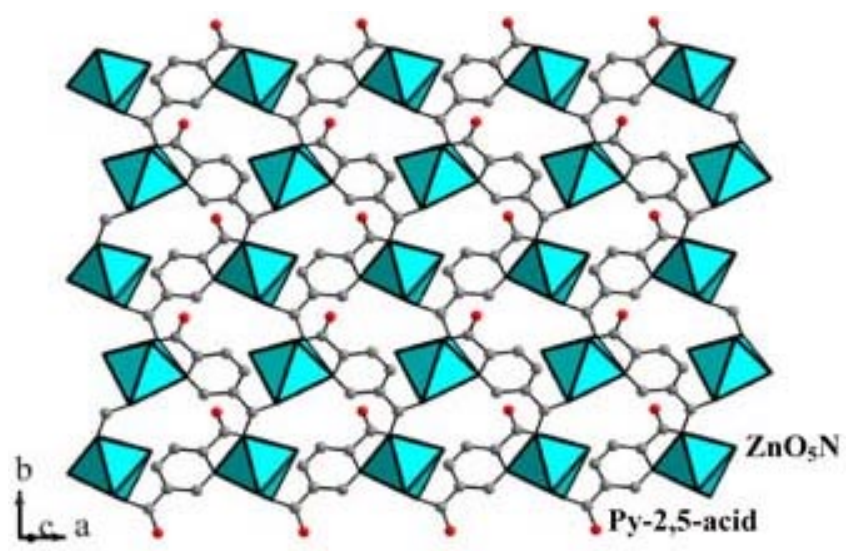

Figure 10. View of the structure of VI in the $a b$ plane showing a single layer. 
the other a bis-bidentate connectivity with the $\mathrm{Gd}^{+3}$ ions. The nitrogen atom of the pyridine ring is bonded only with the $\mathrm{Co}^{+3}$ ions. The connectivity between the polyhedral units and the pyridine carboxylate anions give rise to a two-dimensional neutral layered structure with large apertures bound by 12 -membered ring $\left(3 \mathrm{GdO}_{9}, 3 \mathrm{CoO}_{3} \mathrm{~N}_{3}\right.$ and six pyridine dicarboxylate) (figure 8). The layers are arranged in $A A A A \ldots$ fashion, giving rise to a solid with a supermesh of apertures of $\sim 7 \AA$ free diameter (figure 9). The water molecules, bound to $\mathrm{Gd}$, take part in strong hydrogen bond interactions with the neighbouring non-bonded terminal oxygen atom of the carboxylate $(\mathrm{O} \ldots \mathrm{O}$ distance $=2.85 \AA)$. Such is the disposition of the water molecules within the apertures that there are specific pockets within the apertures (channels) that are hydrophilic.

The asymmetric unit of zinc pyridine-2,5dicarboxylate, $\left\{\mathrm{Zn}\left(\mathrm{H}_{2} \mathrm{O}\right)_{2}\left[\mathrm{C}_{5} \mathrm{~N}_{1} \mathrm{H}_{3}(\mathrm{COO})_{2}\right]\right\} \cdot \mathrm{H}_{2} \mathrm{O}, \mathbf{V I}$, contains 16 non-hydrogen atoms, of which one zinc atom is crystallographically independent. The $\mathrm{Zn}^{+2}$ ions have an octahedral geometry formed by three carboxyalate oxygen atoms, one nitrogen atom of pyridine ring and two oxygen atom of the terminal water molecules. The average distances of $2 \cdot 115 \AA$ for the $\mathrm{Zn}-\mathrm{O}$ and $2.136 \AA$ for the $\mathrm{Zn}-\mathrm{N}$ bonds, result from this connectivity. The $\mathrm{O} / \mathrm{N}-\mathrm{Zn}-\mathrm{O} / \mathrm{N}$ bond angles are in the range $77 \cdot 8(12)-173 \cdot 21(10)^{\circ}$. The selected bond distances are listed in table 2 .

There is only one type of pyridine-2,5-dicarboxylate anion present in the structure. The two carboxylate units of the pyridine-2,5-dicarboxylate show differences in their connectivity with respect to the $\mathrm{Zn}^{+2}$ ions. Thus, the carboxylate group that is the nearest to the nitrogen atom of the pyridine ring has a monodentate connectivity while the other carboxylate group has a bis-bidentate connectivity with the $\mathrm{Zn}^{+2}$ ions. The connectivity between the $\mathrm{ZnO}_{5} \mathrm{~N}$ octahedra and the pyridine carboxylate anions gives rise to a two-dimensional neutral layer structure as shown in figure 10.

\section{Concluding remarks}

The use of hydrothermal methods over the past years has enabled the discovered of many novel materials possessing channels and other features of potential technological applications. It is significant that one is in a somewhat better position today to design these structures based on the understanding of the processes involved in their formation. We are, however, far from being able rationally to design materials with the desired dimensionality or porosity. There is still much to be done to unravel fully the role of the amine and the process(s) involved in the assembly of complex three-dimensional structures from simpler units. One feature that has become apparent is that the formation of open-framework structures is not slow and step-wise throughout, but is likely to involve the spontaneous assembly of preformed units. There is still considerable scope to explore newer structures possessing novel properties such as ferromagnetic channels. It would be of great value if one can find ways to remove the amines present in the channels or between the layers in the open-framework structures. These are some of the challenges at present, but it is clear that the use of hydrothermal technique for the preparation of inorganic compounds continues to be interesting.

\section{Acknowledgments}

SN thanks the Department of Science and Technology, Government of India for the award of a research grant. The authors also thank DST-IRHPA for the CCD facility.

\section{References}

1. Barrer R M 1948 J. Chem. Soc. 2158

2. Barrer R M 1982 Hydrothermal chemistry of zeolites (London: Academic Press)

3. Rao C N R, Natarajan S and Vaidhyanathan R 2004 Angew. Chem. Int. Ed. 421426

4. Cheetham A K, Loiseau T and Ferey G 1999 Angew. Chem. Int. Ed. 383268

5. SMART (V 5.628), SAINT (V 6.45a), XPREP, SHELXTL, Bruker AXS Inc. Madison, Wisconsin, USA, 2004

6. Sheldrick G M 1994 Siemens area correction absorption correction program. University of Göttingen, Göttingen, Germany

7. Sheldrick G M 1997 SHELXL-97 program for crystal structure solution and refinement, University of Göttingen, Göttingen, Germany

8. Farrugia J L 1999 J. Appl. Crystallogr. 32837

9. Brown I D and Altermatt D 1985 Acta Crystallogr. B41 244

10. Chang W-K, Chiang R-K, Jiang Y-C, Wang S-L, Lee S-F and Lii K-H 2004 Inorg. Chem. 432564

11. Huang C-H, Huang L-H, Lii K-H 2001 Inorg. Chem. 402625

12. Huang L-H, Kao H-M and Lii K-H 2002 Inorg. Chem. 412936

13. Natarajan S 2002 Chem. Commun. 780 
14. Thomas J M, Jones R H, Xu R, Chen J, Chippindale A M, Natarajan S and Cheetham A K 1992 J. Chem. Soc., Chem. Commun. 929

15. Jones R H, Thomas J M, Xu R, Huo Q, Cheetham A K and Powell A V 1991 J. Chem. Soc., Chem. Commun. 1266

16. Choudhury A, Natarajan S and Rao C N R 1999 Chem. Mater. 112316

17. Férey G 1995 J. Fluorine Chem. 72187
18. Mandal S, Pati S K, Green M A and Natarajan S 2005 Chem. Mater. 172912

19. Choudhury A, Natarajan S and Rao C N R 1999 J. Solid State Chem. 146538

20. Choudhury A, Natarajan S and Rao C N R 1999 Chem. Commun. 1305

21. Cavellec M, Riou D, Greneche J-M and Ferey G 1997 Inorg. Chem. 362187 